\title{
Modelling of the formulated solid rocket propellant characteristics
}

\author{
Oyedeko K.F.K ${ }^{1, *}$ and Egwenu S. O. ${ }^{2}$ \\ ${ }^{1}$ Department of Chemical Engineering, Lagos State University, Lagos, Nigeria \\ ${ }^{2}$ Rocket propellant unit, Centre for Space Transport and Propulsion, Epe, Lagos Nigeria
}

Global Journal of Engineering and Technology Advances, 2021, 06(02), 061-073

Publication history: Received on 10 January 2021; revised on 06 February 2021; accepted on 08 February 2021

Article DOI: https://doi.org/10.30574/gjeta.2021.6.2.0017

\begin{abstract}
This study is a mathematical model to obtain the characteristics performance of magnesium metal (powder) and carbon on a potassium nitrate-sucrose (KNSU) solid propellant formulation. Characterization of propellant is, as a general rule, important to determine its performance before it can be suitable for use for a rocket flight or any mission. Method of ballistic load cell evaluation was used to validate results and a mathematical model using the combustion exhaust products was solved to obtain the characteristics performance parameters of the propellant. The carbon constituent which acts as an opacifier and coolant was kept constant at $2 \%$ in order to arrest some of the heat during the combustion process and helped to lower the combustion temperature, because high combustion temperature could lead to combustion chamber rupture or failure. The effect of addition of magnesium which was optimized for $3 \%$ in the formulation contributed significantly in improving the overall performance of the propellant. The utilization of magnesium in KNSU propellant provided higher values parameters and better performance compared to when not included. This was confirmed with the model equations. The propellant combustion products equation was used to model and obtain the characteristics performance parameters. This gave propellant specific impulse (122.9s), combustion temperature $(1821 \mathrm{~K})$, heat ratio $(1.1592)$, molecular weight $(36.89 \mathrm{~g} / \mathrm{mole})$, propellant density $(1912.5 \mathrm{~kg} / \mathrm{m} 3)$ and characteristics velocity $(1000 \mathrm{~m} / \mathrm{s})$ result while maintaining the same chamber pressure.
\end{abstract}

Keywords: Magnesium metal; Mathematical model; Carbon; Potassium nitrate- sucrose; Ballistic load

\section{Introduction}

All Solid Rocket Motors have the same form of principle but there is universal design method to utilize for design of various subsystems of Solid Rocket Motors such as the propellant. For example, approach to propellant to be formulated may vary with mission scenario, background experience and class of application.

For applications of rocket either for unguided military mission for upper atmosphere or any launch vehicle for space missions, the optimum Solid Rocket Motors design has to satisfy optimum total impulse, an optimium thrust-time profile, an optimum nozzle configuration an optimum chamber pressure and a preferred solid propellant grain configuration $[1,2]$

Classification of propellants in respect of the physical state of the fuel and oxidizer constituents of the propellant are solid propellants, liquid propellants and hybrid propellants [3]. Solid propellants have been the commonly used due to reliability, cost effective and simple to design [4,5]. Different formulations of various combinations of chemical constituents would give propellants of different physical and chemical properties, as well as combustion characteristics and performance $[4,5]$.

\footnotetext{
${ }^{*}$ Corresponding author: Oyedeko K.F.K

Lagos State University, Department of Chemical Engineering.
}

Copyright $@ 2021$ Author(s) retain the copyright of this article. This article is published under the terms of the Creative Commons Attribution Liscense 4.0. 
The preferable use of Solid Chemical propellant (SCP) by many designers and manufacturers in different forms of rockets are due mainly to the advantageous area over the others chemical propellants with respect to simplicity of production, cost effectiveness, and dependable in terms of storage time and performance chemical potential energy [6].

The selection of propellant is usually carried out at the early stage of Solid Rocket Motors design based on the performance of the rocket and the available knowledge of the designer and manufacturer. It is therefore important to explore propellants of better performance characteristics with less mass (weight) to hit higher attitudes.[2,7,8]

The specific impulse, burning rate, temperature sensitivity, density and specific heat ratio are propellant properties that represent independent design variables [9]

Researchers have been working extensively to obtain the optimal design for a rocket vehicle that would achieve the safety, operability, reliability, performance and cost objectives of a rocket [10]

One of the main objectives in many rocket optimisation is minimizing the gross lift off mass/weight $[11,12,13,14,15,16]$

Traditionally the total vehicle mass (inert mass and propellant mass) are seen as a primary driver towards the final vehicle cost, as cost is always an essential factor developing the rocket based vehicle [1]

Many researchers have been working over the years to improve and develop new propellant formulations significantly to meet the need of the type reaching targets and missions with less weight [4,5] and propellant mass fraction can be sometimes be up to $70-90 \%$ of the rocket total mass, then improving and developing new propellant formulations to meet this need is therefore very significant)[12,14,17]

The aim of this work is to improve the performance of a KNSU rocket propellant fuel using magnesium metal and carbon. As KNSU has some shortcomings of brittleness, hygroscopic nature and caramelization amongst others [6,18]. The objectives are to: model the thermodynamics characterization and ballistic properties of the propellant . Validate the predicted propellant properties such as pressure and thrust generated by the propellant to characterize the fuel. These are to achieve: higher specific impulse, less smoke or reduced smoke, more flame, less hygroscopic propellant, less brittle, thus it can withstand more stress during handling without breaking, lower propellant mass to reach higher altitude.

\section{Material and methods}

This method involves performance parameters measurements mathematical model development and model validation of the propellant. The propellant constituents used are oxidizer (potassium nitrate), fuel or binder (sucrose), fuel (magnesium) and opacifier (carbon). The propellant characteristics performance parameters of interest in this work are the specific impulse, density, combustion temperature, characteristic velocity, molecular weight and heat ratio of the propellant.

\subsection{Mathematical Modeling of the Propellant Characterization}

Mathematical modeling of the propellant performance parameters using the propellant combustion equation was used to relate the propellant formulation and to characterize it.

\subsubsection{Combustion temperature modeling}

A rocket motor operates on the basic principle of converting heat energy, from chemical reactions, to kinetic energy. Thus it is essential to know the temperature delivered by the propellant to the combustion chamber; analytically we can calculate the adiabatic flame temperature gotten from, as a result of our balanced chemical equation.

Using the propellant combustion products balance equation (assuming no changes in kinetic energy and potential energy)

$$
\begin{aligned}
& 6.3 \mathrm{KNO}_{3(s)}+0.9 \mathrm{C}_{12} \mathrm{H}_{22} \mathrm{O}_{11(s)}+1.1 \mathrm{Mg}(s) \\
& 3.35 \mathrm{H}_{2}+3.15 \mathrm{~N}_{2(g)}+3.1 \mathrm{CO}_{2(g)}+2.7 \mathrm{~K}_{2} \mathrm{CO}_{3(l)}+1.1 \mathrm{MgO} \mathrm{O}_{(s)}+0.9 \mathrm{KOH}_{(g)}
\end{aligned}
$$

Enthalpy of reactants = Enthalpy of products. 
$H_{R}=H_{P}$

$\sum_{R} n_{i}\left[\bar{h}_{f}^{o}+\Delta \bar{h}\right]=\sum_{p} n e\left[\bar{h}_{f}^{o}+\Delta \bar{h}\right]_{o}$

The enthalpies of formation values are now applied to equation (1) as shown in Table 1

Table 1 Enthalpies of Formation of Elements and Compounds Used at 298.15K (Source: NIST chemistry web book).

\begin{tabular}{|l|l|l|}
\hline Constituents & States & $\bar{h}_{\boldsymbol{f}}^{\boldsymbol{o}}(\mathbf{K J} / \mathbf{m o l})$ \\
\hline $\mathrm{KNO}_{3}$ & Solid & -494.63 \\
\hline $\mathrm{C}_{12} \mathrm{H}_{22} \mathrm{O}_{11}$ & Solid & -2226.1 \\
\hline $\mathrm{Mg}$ & Solid & 0 \\
\hline $\mathrm{C}$ & Solid & 0 \\
\hline $\mathrm{CO}$ & Gas & -110.53 \\
\hline $\mathrm{H}_{2} \mathrm{O}$ & Gas & -241.83 \\
\hline $\mathrm{H}_{2}$ & Gas & 0 \\
\hline $\mathrm{N}_{2}$ & Gas & 0 \\
\hline $\mathrm{CO} 2$ & Gas & -393.52 \\
\hline $\mathrm{K}_{2} \mathrm{CO}{ }_{3}$ & Liquid & -1150.18 \\
\hline $\mathrm{MgO}$ & Solid & -601.8 \\
\hline $\mathrm{KOH}$ & Gas & -424.72 \\
\hline
\end{tabular}

The enthalpies of formation can be gotten from CRC hand book of chemistry and physics [19] or thermo-chemical tables NIST chemistry web book. [20]

Using the above equation and substituting in the values for $h_{f}, n_{i}$ and $n_{e}$ gives;

$6.3(-494.63+0)+0.9(-2226.1+0)+1.1(0)+1.4(0)=6.4(-110.53+C O)+6.1\left(-241.83+\mathrm{H}_{2} \mathrm{O}\right)+$ $3.35\left(0+\mathrm{H}_{2}\right)+3.15\left(0+\mathrm{N}_{2}\right)+3.1\left(-393.52+\mathrm{CO}_{2}\right)+2.7\left(-1150.18+\mathrm{K}_{2} \mathrm{CO}_{3}\right)+1.1(-601.8+\mathrm{MgO})$

$+0.9(-424.72+\mathrm{KOH})$

$-5119.66=(-707.2+6.4 \mathrm{CO})+\left(-1475.16+6.1 \mathrm{H}_{2} \mathrm{O}\right)+\left(0+3.35 \mathrm{H}_{2}\right)+\left(0+3.15 \mathrm{~N}_{2}\right)+$

$\left(-1219.92+3.1 \mathrm{CO}_{2}\right)+\left(-3052.65+2.7 \mathrm{~K}_{2} \mathrm{CO}_{3}\right)+(-661.98+1.1 \mathrm{MgO})+(-208.935+0.9 \mathrm{KOH})$

We collect like terms and thus:

$-5119.66+7325.8=6.4 \mathrm{CO}+6.1 \mathrm{H}_{2} \mathrm{O}+3.35 \mathrm{H}_{2}+3.15 \mathrm{~N}_{2}+3.1 \mathrm{CO}_{2}+2.7 \mathrm{~K}_{2} \mathrm{CO}_{3}+1.1 \mathrm{MgO}+0.9 \mathrm{KOH}$

$2206.184=6.4 \mathrm{CO}+6.1 \mathrm{H}_{2} \mathrm{O}+3.35 \mathrm{H}_{2}+3.15 \mathrm{~N}_{2}+3.1 \mathrm{CO}_{2}+2.7 \mathrm{~K}_{2} \mathrm{CO}_{3}+1.1 \mathrm{MgO}+0.9 \mathrm{KOH}$

The solution of the equation is obtained by simply substituting in values for at a certain temperature. This temperature is equal to the adiabatic flame temperature (AFT) when the right hand side of the equation is equal to the left hand side (=2206.184K). 
After much iteration it was found out that AFT lies between say 1800K - 1900K. From Joint Army-Navy-NASA-Air Force (JANNAF) tables, [21] the values are as shown in Table 2.

Table 2 Enthalpy of Formation of Product Species at $1800 \mathrm{~K}$ and $1900 \mathrm{~K}$.

\begin{tabular}{|l|l|l|}
\hline Species & Values @1900K (KJ/mole) & Values @1800K(KJ/mole) \\
\hline $\mathrm{CO}$ & 53.126 & 49.526 \\
\hline $\mathrm{H} 20$ & 67.706 & 62.693 \\
\hline $\mathrm{H} 2$ & 49.541 & 46.169 \\
\hline $\mathrm{N} 2$ & 52.548 & 48.978 \\
\hline $\mathrm{CO} 2$ & 85.419 & 79.431 \\
\hline $\mathrm{K} 2 \mathrm{CO} 3$ & 302.542 & 281.622 \\
\hline $\mathrm{MgO}$ & 81.065 & 75.558 \\
\hline $\mathrm{KOH}$ & 88.052 & 82.216 \\
\hline
\end{tabular}

Iterating at $1900 \mathrm{~K}$ and substituting,

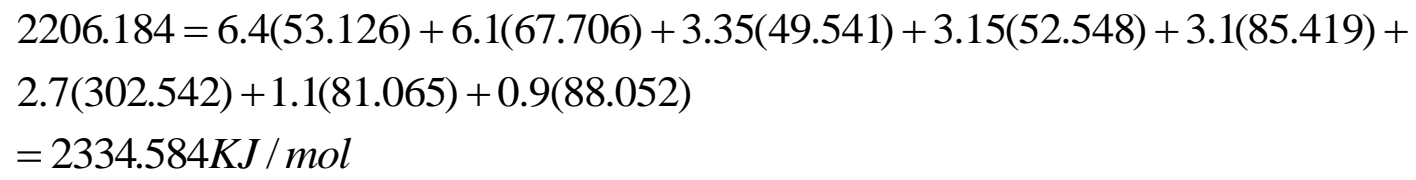

Iterating at $1800 \mathrm{~K}$ and substituting,

$$
\begin{aligned}
& 2206.184=6.4(49.526)+6.1(62.693)+3.35(46.169)+3.15(48.978)+3.1(79.431)+ \\
& 2.7(281.622)+1.1(75.558)+0.9(82.216) \\
& =2172.064 \mathrm{KJ} / \mathrm{mol}
\end{aligned}
$$

From here, we can see that the adiabatic flame temperature for the reaction lies between $1800 \mathrm{~K}$ and $1900 \mathrm{~K}$. Therefore we interpolate to locate the particular temperature as follows:

$$
\begin{array}{ll}
=2334.584 \mathrm{KJ} / \mathrm{mol} & 1900 \mathrm{~K} \\
=2206 . .184 \mathrm{KJ} / \mathrm{mol} & \text { AFT }(\mathrm{xK}) \\
=2172.064 \mathrm{KJ} / \mathrm{mol} & 1800 \mathrm{~K} \\
\frac{1900-1800}{1900-x^{0} \mathrm{~K}}=\frac{2334.584-2172.064}{2334.584-2206.184} & \\
\frac{100}{1900-x K}=\frac{162.520}{128.400}=1.2657 & \\
x(A F T)=182 \mathrm{~K} &
\end{array}
$$

Thus the theoretical adiabatic flame temperature of the propellant is $1821 \mathrm{~K}$ 
Specific heats ratio, $\mathrm{k}$

The specific heat ratio of a mixture is defined by [4] the equation

$k=\frac{C_{p_{m i x}}}{C_{v}}$

$k=\frac{C_{p_{\operatorname{mix}}}}{C_{p_{\text {mix }}}-R}$

$k=\frac{1}{1-\frac{R}{C_{\text {pmix }}}}$

Where $C_{p_{m i x}}=\frac{1}{n_{T}\left[\sum\left(n_{i} C_{p i}\right)+\left(n_{s} C_{p s}\right)\right]}$

$n_{T}=$ total number of gas moles

$n_{i}=$ number of moles of gas component $\mathrm{i}$

$C_{p i}=$ specific heat capacity of gas component $\mathrm{i}$

$n_{s}=$ number of moles of condensed phase product

$C_{p s}=$ specific heat capacity of condensed phase product

Specific heat determination

$C_{P_{\text {mix }}}=\frac{1}{n_{T}}\left(\begin{array}{l}n_{\mathrm{CO}} C_{P_{c o}}+n_{\mathrm{H}_{2} \mathrm{O}} C_{P_{\mathrm{H}_{2} \mathrm{O}}}+n_{\mathrm{H}_{2}} C_{P_{\mathrm{H}_{2}}}+n_{\mathrm{N}_{2}} C_{P_{\mathrm{N}_{2}}}+n_{\mathrm{CO}_{2}} C_{\mathrm{P}_{\mathrm{CO}_{2}}}+n_{\mathrm{K}_{2} \mathrm{CO}_{3}} C_{\mathrm{P}_{\mathrm{K}_{2} \mathrm{CO}_{3}}}+ \\ n_{\mathrm{MgO} O} C_{p_{\mathrm{MgO}_{\mathrm{O}}}}+n_{\mathrm{KOH}} C_{P_{\mathrm{KOH}}}\end{array}\right)$

The specific heat $\left(C_{p}\right)$ of species values at $1800 \mathrm{k}$ and $1900 \mathrm{~K}$ as shown in Table 3.

Table 3 Specific Heat (Cp) of Product Species at $1800 \mathrm{~K}$ and $1900 \mathrm{~K}$

\begin{tabular}{|l|l|l|}
\hline Species & Values @ 1900K (J/kmol) & Values @ 1800K(J/kmol) \\
\hline $\mathrm{CO}$ & 36.091 & 35.911 \\
\hline $\mathrm{H}_{2} \mathrm{O}$ & 50.496 & 49.749 \\
\hline $\mathrm{H}_{2}$ & 33.917 & 33.537 \\
\hline $\mathrm{N}_{2}$ & 35.796 & 35.6 \\
\hline $\mathrm{CO}_{2}$ & 85.419 & 59.701 \\
\hline $\mathrm{K}_{2} \mathrm{CO}_{3}$ & 209.2 & 209.2 \\
\hline $\mathrm{MgO}$ & 55.278 & 54.204 \\
\hline $\mathrm{KOH}$ & 58.504 & 58.204 \\
\hline
\end{tabular}


By extrapolation, $C_{p} @ 1821 K$, we have

Table 4 Extrapolated Specific Heat (Cp) of Product Species at 1821K (AFT)

\begin{tabular}{|l|l|l|}
\hline Species & State & Values @ $1821 K_{(\mathbf{J} / \mathbf{k m o l})}$ \\
\hline CO & Gas & 35.949 \\
\hline H20 & Gas & 49.906 \\
\hline H2 & Gas & 33.617 \\
\hline N2 & Gas & 35.6 \\
\hline CO2 & Gas & 59.701 \\
\hline K2CO3 & Liquid & 209.2 \\
\hline MgO & Solid & 54.978 \\
\hline KOH & Gas & 58.267 \\
\hline
\end{tabular}

$\mathrm{n}_{\text {Tgas }}=$ total number of gas moles

$\mathrm{n}_{\mathrm{Ti}}=$ total number of moles in mixture

$n_{T_{\text {gas }}}=n_{\mathrm{CO}}+n_{\mathrm{H}_{2} \mathrm{O}}+n_{\mathrm{H}_{2}}+n_{\mathrm{N}_{2}}+n_{\mathrm{CO}_{2}}+n_{\mathrm{KOH}}$

$n_{T_{\text {gas }}}=6.4+6.1+3.35+3.15+3.1+0.9=23$ moles

$n_{\mathrm{Ti}}=n_{\mathrm{CO}}+n_{\mathrm{H}_{2} \mathrm{O}}+n_{\mathrm{H}_{2}}+n_{\mathrm{N}_{2}}+n_{\mathrm{CO}_{2}}+n_{\mathrm{K}_{2} \mathrm{CO}_{3}}+n_{\mathrm{MgO}}+n_{\mathrm{KOH}}$

$n_{T i}=n_{T m i x}=6.4+6.1+3.35+3.15+3.1+2.7+1.1+0.9=26.8$ moles

$C_{P_{\text {gas }}}=\frac{1}{23}\left(\begin{array}{l}(6.4 \times 35.949)+(6.1 \times 49.906)+(3.35 \times 33.617)+(3.15 \times 35.641)+(3.1 \times 59.774)+ \\ (0.9 \times 58.267)\end{array}\right)$

$C_{P_{\text {gas }}}=43.70268\left(\mathrm{JK}^{-1} \mathrm{~mol}^{-1}\right)$

$C_{P_{\text {mix }}}=\frac{1}{26.8}\left(\begin{array}{l}(6.4 \times 35.949)+(6.1 \times 49.906)+(3.35 \times 33.617)+(3.15 \times 35.641)+(3.1 \times 59.774)+ \\ (2.7 \times 209.2)+(1.1 \times 54.978)+(0.9 \times 58.267)\end{array}\right)$

$C_{P_{\text {mix }}}=60.53887\left(\mathrm{JK}^{-1} \mathrm{~mol}^{-1}\right)$

Where R= universal gas constant, $R=8.314(\mathrm{~J} / \mathrm{molK})$

$\mathrm{C}_{\mathrm{V}}=$ specific heat at constant volume

$C_{V}=60.53887-8.314=52.22487$

$k_{\text {mix }}=\frac{C_{P}}{C_{V}}=\frac{60.53887}{52.22487}=1.1591$ 
$k_{\text {mix }}=1.1591$

Effective molecular weight of the mix calculation:

Using the combustion equation,

Table 5 Moles and Mass of the product species of the combustion equation

\begin{tabular}{|l|r|r|}
\hline $\begin{array}{l}\text { Product } \\
\text { species }\end{array}$ & $\begin{array}{l}\text { Moles, } \\
\mathrm{n}\end{array}$ & \multicolumn{1}{|c|}{$\begin{array}{c}\text { Mass of Products species, } \\
\mathrm{mp}(\mathrm{g})\end{array}$} \\
\hline $\mathrm{CO} 2$ & 3.1 & 136.4295 \\
\hline $\mathrm{CO}$ & 6.4 & 179.2646 \\
\hline $\mathrm{H} 2 \mathrm{O}$ & 6.1 & 109.8932 \\
\hline $\mathrm{H} 2$ & 3.35 & 6.7532 \\
\hline $\mathrm{N} 2$ & 3.15 & 88.2422 \\
\hline $\mathrm{K} 2 \mathrm{CO} 3$ & 2.7 & 373.1549 \\
\hline $\mathrm{KOH}$ & 0.9 & 50.4951 \\
\hline $\mathrm{MgO}$ & 1.1 & 44.3348 \\
\hline & & \\
\hline
\end{tabular}

Therefore, the molecular weight given as:

$$
\begin{aligned}
& M W=\frac{\sum m p}{\sum n_{i}} \\
& =\frac{988.567}{26.8}=36.8868 \mathrm{~g} / \mathrm{mol}
\end{aligned}
$$

\subsection{Other Characteristics Performance Parameters}

The other mathematical calculation evaluation of the propellant performance parameters such as the propellant specific impulse, propellant density and molecular weight were computed using MATHCAD tool.

\subsubsection{Propellant Specific impulse (Isp) calculation}

Acceleration due to gravity: $g_{\text {acc }}=9.81 \mathrm{~m} / \mathrm{s}^{2}$

Nozzle exit pressure: $\mathrm{Pe}_{\mathrm{e}}=14.7 \mathrm{psi}$

Chamber combustion pressure: $\mathrm{P}_{\mathrm{o}}=112 \mathrm{psi}$

Propellant specific impulse, Isp

$$
\begin{aligned}
I_{S P} & =\frac{1}{g_{a c c}}\left[\left[2 T_{C} \frac{R_{u}}{M}\left(\frac{k}{k-1}\right)\right]\left[1-\left(\frac{P_{e}}{P_{o}}\right)^{\frac{k-1}{k}}\right]\right]^{\frac{1}{2}} \\
I_{S P} & =122.9 \mathrm{~S}
\end{aligned}
$$


2.2.2. Characteristics Velocity, C-star

Temperature: $\mathrm{T}_{\mathrm{c}}=1821 \mathrm{~K}$

The universal gas constant: $R_{u}=831 \mathrm{~J} / \mathrm{kgmol} \mathrm{K}$

The Molecular Weight of the propellant: $\mathrm{M}=36.8868 \mathrm{~g} / \mathrm{mol}$

The Propellant Gas Constant: $R_{g}=\frac{R_{u}}{M}=225.392 \mathrm{~J} / \mathrm{kgK}$

The specific heat ratio: $\mathrm{k}=1.15919$

Characteristic velocity, c-star

$$
\begin{gathered}
C_{\text {star }}=\left[\left(\frac{R_{g} T_{c}}{k}\right)\left(\frac{k+1}{2}\right)^{\left(\frac{k+1}{k-1}\right)}\right]^{\frac{1}{2}} \\
C_{\text {star }}=1000.264 \mathrm{~m} / \mathrm{s}
\end{gathered}
$$

2.2.3. Ideal Density of the Mix Calculation for KNSUMgC Propellant

\% composition of oxidizer: $F_{\mathrm{KNO}_{3}}=0.65$

$\%$ composition of sucrose fuel: $F_{S U}=0.30$

$\%$ composition of magnesium fuel: $F_{M g}=0.03$

\% composition of opacifier carbon: $F_{C}=0.02$

$$
F_{\text {total }}=F_{\mathrm{KNO}_{3}}+F_{\mathrm{SU}}+F_{M g}+F_{C}=
$$

\subsubsection{Ideal Density}

Density of KNO3 oxidizer: $\rho_{\mathrm{KNO}_{3}}=2110 \mathrm{~kg} / \mathrm{m}^{3}$

Density of Sucrose fuel: $\rho_{S U}=1590 \mathrm{~kg} / \mathrm{m}^{3}$

Density of Magnesium fuel: $\rho_{M g}=1740 \mathrm{~kg} / \mathrm{m}^{3}$

Density of opacifier carbon: $\rho_{C}=2250 \mathrm{~kg} / \mathrm{m}^{3}$ 


$$
\text { Density }_{\text {mix }}=\frac{1}{\left(\frac{F_{K N O_{3}}}{\rho_{K N O_{3}}}\right)+\left(\frac{F_{S U}}{\rho_{S U}}\right)+\left(\frac{F_{M g}}{\rho_{M g}}\right)+\left(\frac{F_{C}}{\rho_{C}}\right)} \mathrm{kg} / \mathrm{m}^{3}
$$

$$
\text { Density }_{\text {mix }}=1912.534 \mathrm{~kg} / \mathrm{m}^{3}
$$

\section{Results and discussion}

The experimental results from the load cell, software results and mathematical calculations carried out are presented in Tables 6 to 8 and Figures 1 to 3.

Table 6 Results of Software, Validation Test and Mathematical Model

\begin{tabular}{|l|l|l|l|l|l|}
\hline Parameter & Notation & PROPEP & VALIDATION TEST & MODEL & Unit \\
\hline Specific impulse & Isp & 118.5 & 117.9 & 122.9 & $\mathrm{~s}$ \\
\hline Combustion Temperature & Tc & 1873 & 1818 & 1821 & $\mathrm{~K}$ \\
\hline Molecular Weight & MW & 37.34 & 38.88 & 36.89 & $\mathrm{~g} / \mathrm{mole}$ \\
\hline Isentropic heat ratio & K & 1.1317 & 1.1508 & 1.1592 & - \\
\hline Propellant Density & $\rho_{p}$ & 1910 & 1874.6 & 1912.5 & $\mathrm{~kg} / \mathrm{m}^{3}$ \\
\hline Characteristic velocity & c-star & 950 & 997.2 & 1000 & $\mathrm{~m} / \mathrm{s}$ \\
\hline
\end{tabular}

Table 7 Ballistic Load Cell Results of Propellant Samples

\begin{tabular}{|l|l|l|l|l|}
\hline $\begin{array}{l}\text { Propellant } \\
\text { Samples }\end{array}$ & $\begin{array}{l}\text { \%Mg } \\
\text { Composition }\end{array}$ & $\begin{array}{l}\text { Exit Temperature } \\
\text { Te (K) }\end{array}$ & $\begin{array}{l}\text { Thrust } \\
\text { F(N) }\end{array}$ & $\begin{array}{l}\text { Burn time } \\
\text { tb(s) }\end{array}$ \\
\hline Control & 0 & 113 & 1017 & 3.93 \\
\hline 1 & 0 & 1108 & 1013 & 3.9 \\
\hline 2 & 1 & 1191 & 1018 & 4.0 \\
\hline 3 & 2 & 1222 & 1022 & 3.88 \\
\hline 4 & 3 & 1301 & 1027 & 4.0 \\
\hline 5 & 4 & 1297 & 987 & 4.12 \\
\hline 6 & 5 & 1278 & 934 & 4.26 \\
\hline 7 & 6 & 1267 & 894 & 4.31 \\
\hline 8 & 7 & 1214 & 887 & 4.33 \\
\hline 9 & 8 & 1056 & 827 & 4.4 \\
\hline 10 & 9 & 1034 & 805 & 4.51 \\
\hline 11 & 10 & 1013 & 782 & 4.6 \\
\hline
\end{tabular}


Table 8 Result of Propellant Characteristics Performance Parameters

\begin{tabular}{|c|c|c|c|c|c|c|}
\hline $\begin{array}{l}\text { Propellant } \\
\text { Samples }\end{array}$ & $\begin{array}{l}\text { Specific } \\
\text { impulse, } \\
\text { Isp (s) }\end{array}$ & $\begin{array}{l}\text { Heat } \\
\text { ratio, } \\
\mathrm{K}\end{array}$ & $\begin{array}{l}\text { Chamber } \\
\text { Temp., } \\
\text { Tc (K) }\end{array}$ & $\begin{array}{l}\text { Characteristic } \\
\text { velocity, } \\
\text { C-star (m/s) }\end{array}$ & $\begin{array}{l}\text { Propellant } \\
\text { density, } \\
\rho_{p}\left(\mathrm{~kg} / \mathrm{m}^{3}\right)\end{array}$ & $\begin{array}{l}\text { Molecular } \\
\text { weight } \\
\text { Mw (g/mole) }\end{array}$ \\
\hline Control & 114.8 & 1.1512 & 1576 & 973.2 & 1899 & 36.59 \\
\hline 1 & 113.4 & 1.1547 & 1568 & 963.3 & 1904 & 36.86 \\
\hline 2 & 116.9 & 1.1524 & 1677 & 989.4 & 1906 & 37.09 \\
\hline 3 & 113.9 & 1.1511 & 1716 & 966.5 & 1908 & 37.24 \\
\hline 4 & 118.0 & 1.1508 & 1826 & 997.2 & 1910 & 37.33 \\
\hline 5 & 116.8 & 1.1497 & 1816 & 988.3 & 1912 & 37.36 \\
\hline 6 & 114.3 & 1.1487 & 1786 & 969.4 & 1914 & 37.34 \\
\hline 7 & 110.6 & 1.1468 & 1764 & 942.3 & 1916 & 37.28 \\
\hline 8 & 110.3 & 1.1456 & 1686 & 939.6 & 1918 & 37.18 \\
\hline 9 & 104.5 & 1.1444 & 1463 & 896.1 & 1920 & 37.06 \\
\hline 10 & 104.2 & 1.1432 & 1429 & 894.3 & 1922 & 36.9 \\
\hline 11 & 103.3 & 1.1425 & 1398 & 887.1 & 1924 & 36.74 \\
\hline
\end{tabular}

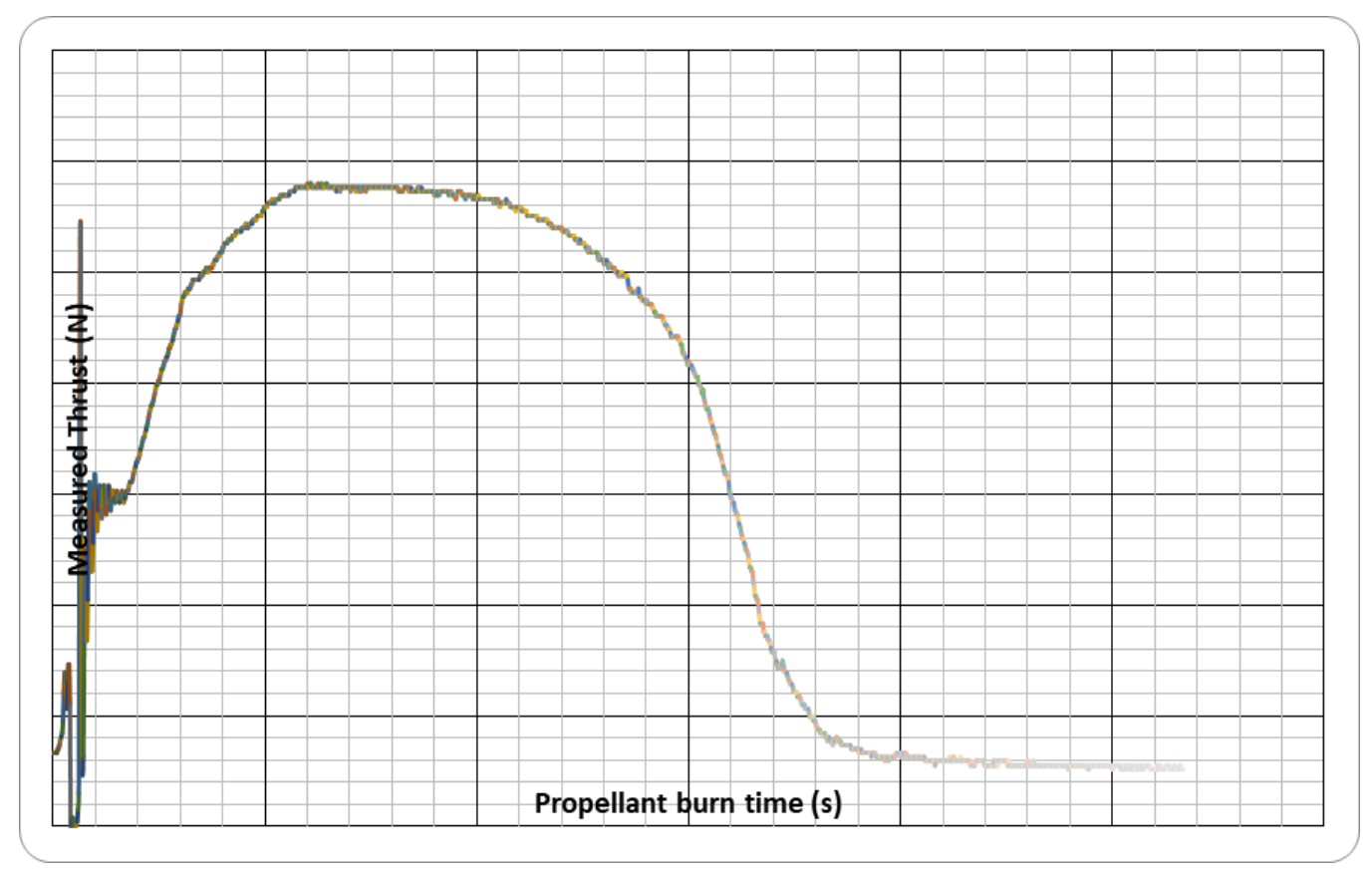

Figure 1 Measured Thrust and Burn Time Curve 


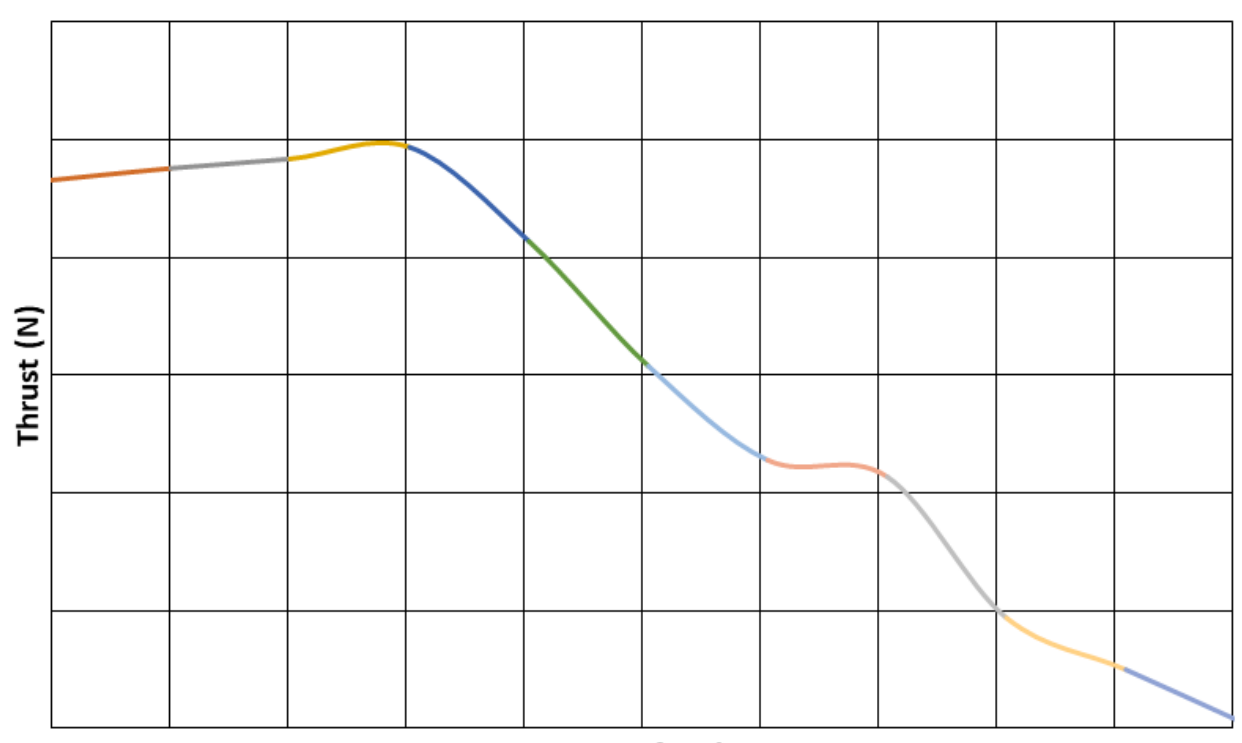

Mg mass fraction

Figure 2 Thrust vs. Magnesium Mass Fraction Curve

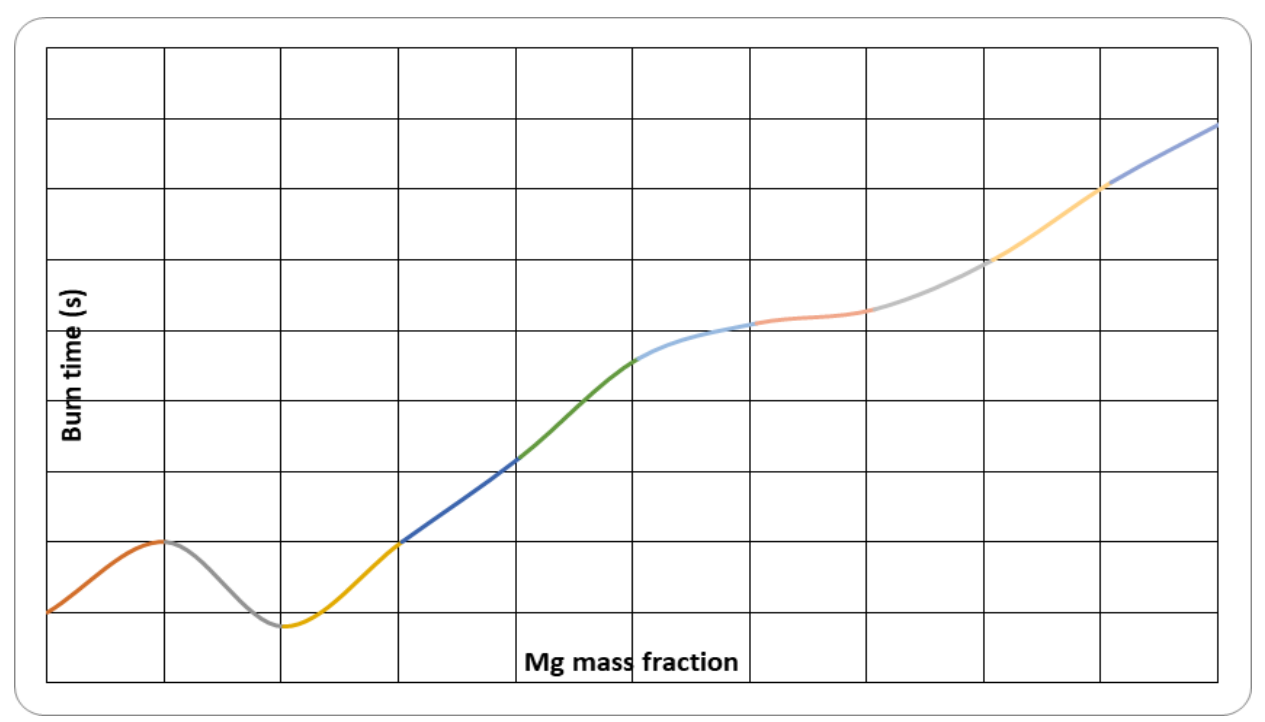

Figure 3 Propellant burn time vs. Magnesium Mass Fraction Curve

\section{Discussion}

The load cell instrumentation was helpful in determining the thrust generated by the propellant and the duration of the burn, usually referred to as the burn time. The propellant combustion products equation (1) was used to model and obtain the characteristics performance parameters. This gave propellant specific impulse (122.9s), combustion temperature $(1821 \mathrm{~K})$, heat ratio $(1.1592)$, molecular weight $(36.89 \mathrm{~g} / \mathrm{mole})$, propellant density $\left(1912.5 \mathrm{~kg} / \mathrm{m}^{3}\right)$ and characteristics velocity $(1000 \mathrm{~m} / \mathrm{s})$ result while maintaining the same chamber pressure.

It was observed that utilization of a propellant evaluation program (software) to compare the propellant formulation with that of the , mathematical model showed that their results were close to the result obtained indicating, that basic assumptions made in the mathematical solutions were valid.

Table 8 is the test results (samples 1-11) that showed the effect of addition of magnesium to the propellant formulation and revealed that parameters such as specific impulse, chamber temperature, characteristics velocity, heat ratio were 
greatly improved as compare to when magnesium was not present in the formulation. Figure 3 showed the result of magnesium on the propellant burn time. Magnesium was found to be increasing the propellant burn time and forced the sucrose from burning so spontaneously and aggressively resulting in shorter burn time.

It was observed that addition of magnesium to the formulation really justified by the amount of improvement brought upon the propellant performance. The need to necessarily select and use a propellant of higher composition of magnesium of average cost for parameters such as specific impulse, thrust, characteristic velocity, chamber temperature, thrust coefficient and heat ratio are raised to desired points is justified(22).

The utilization of $2 \%$ carbon which acted as an opacifier and/or coolant helped to contain some of the heat during the combustion process from directly hitting the walls of the motor thereby limiting or reducing high combustion temperature that could lead to the rocket motor rupture or failure. In this case, when increased beyond this percentage, the propellant was excessively smoky. Smoky fuel is the presence of high magnesium oxide (MgO) and other solids in the combustion products which result in air pollution, and can be harmful to human lives and the environment. A Smoky fuel is usually avoided especially in military application. (22) Also, carbon helped in aiding the curing of the propellant, improve the physical and mechanical properties such as plasticity (rubbery-like) textures.

\section{Conclusion}

The mathematical modeling of the combustion exhaust products was employed to characterize the propellant and results well agreed with experimental ballistic test results as well as the software result-PROPEP, which is a software program designed for the characterization of solid rocket motor propellants. This also confirmed the experimental results that inclusion of magnesium in the propellant formulation significantly improved the overall performance parameters of the propellant. The higher the values of these parameters, the better the performance of the propellant.

The use of magnesium adequately reduces the challenge of a smoky propellant that the KNSU propellant produces, improved the specific impulse and thrust generated.

This work has therefore solved the challenge of hygroscopicity of sugar propellants and improved the characteristics performance parameters of such propellants.

Rocket-grade chemical ingredients are recommended to be used to get characteristics performance results close to that of the software performance results.

\section{Compliance with ethical standards}

\section{Acknowledgments}

We sincerely appreciate the contribution of Dr Adeniyi Gbadebo (head, rocket propellant unit), Engr Wole Onibon-oje, (head, combustion engines and rocket propellant division) and Dr Adetoro Lanre Moshood for the propulsion instrumentation used in this work (head, electronics and simulation division). All of Centre for Space Transport and Propulsion, Epe Lagos

\section{Disclosure of conflict of interest}

There are no conflicts of interest

\section{References}

[1] Bayley D, Hartfield R. Design Optimization of Space Launch Vehicles for Minimum Cost Using a Genetic Algorithm, 43rd AIAA/ASME/SAE/ASEE Joint Propulsion Conference \& Exhibit, AIAA Paper. July 2007; 2007-5852

[2] Biblarz O, Sutton GP. Rocket Propulsion Elements,Wiley, New Jersey. 2010; 792.

[3] Space Travel Guide. Web, 5 January 2014

[4] Yildirim C,Arksel M. Numericcal simulation of the grain burnback in Solid propellant rocket motor. In proceedings of the 4thAIAA/ASME/SAE/SEE Joint proportion Conferencce and Exhibition. Tucson Arizona, USA. 2005. 
[5] Yildirim C. Analysis of Grain Burn back and Internal Flow In Solid Propellant Rocket Motors in 3-Dimensions, Ph. D. Dissertation,Department of Mechanical Engineering, METU. 2007; 110-118.

[6] Mahjub Ahmed, Mazlan,Nurul Musfirah, Abdullah MZ, Azam Qummare. Design Optimization of Solid Rocket Propulsion: A Survey of Recent Advancements. Journal of Spacecraft and Rockets. November 2019.

[7] Sforzini R. An Automated Approach to Design of Solid RocketsUtilizing a Special Internal Ballistics Model, 16th Joint Propulsion Conference, AIAA Paper. June-July 1980; 1980-1135.

[8] Sforzini RH. Automated Approach to Design of Solid Rockets.Journal ofSpacecraft and Rockets. 1981;18(3): 200205.

[9] Solid Propellant Grain Design and Internal Ballistics, NASA SP-8076. 1972.

[10] Rowell LF, Korte JJ. LaunchVehicle Design and Optimization Methods and Priority for the Advanced Engineering Environment, NASA TM-. 2003;2003-212654.

[11] Anderson M, Burkhalter J, Jenkins R. Multi-Disciplinary Intelligent Systems Approach to Solid Rocket Motor Design. I. Single and Dual Goal Optimization, 37th Joint Propulsion Conference and Exhibit, AIAA Paper. 2001; 2001- 3599.

[12] Gbadebo Omoniyi Adeniyi, Jamiu Adetayo Adeniran, Adewole Johnson Adesanmi, Funsho Alaba Akeredolu, Jacob Ademola Sonibare. Optimisation and performance evaluation of an environmentally friendly rocket composite propellant, Indian Chemical Engineer. 2018.

[13] Jodei J, Ebrahimi M, Roshanian J. Multidisciplinary Design Optimization of a Small Solid Propellant Launch Vehicle Using System Sensitivity Analysis," Structural and Multidisciplinary Optimization. 2009;38(1): 93- 100.

[14] Rafique A, He L, Zeeshan Q, Kamran A, Nisar K.Multidisciplinary Design and Optimization of an Air Launched Satellite Launch Vehicle Using a Hybrid Heuristic Search Algorithm, Engineering Optimization. 2011;43(3): 305328.

[15] Roshanian J, Ebrahimi M. Latin Hypercube Sampling Applied to Reliability-Based Multidisciplinary Design Optimization of a Launch Vehicle. Aerospace Science and Technology. 2013;28(1): 297-304.

[16] Tekinalp 0, Utalay S. Simulated Annealing for Missile Trajectory Planning and Multidisciplinary Missile Design Optimization, 38th Aerospace Sciences Meeting and Exhibit, AIAA Paper. Jan. 2000; 2000-684.

[17] Oyedeko KF, Onyieagho A. Effect of Propellant Formulation on Propellant Properties. International Journal of Engineering Sciences \&Research Technology. 2018; 7(8): 305-313.

[18] Sutton GP,Biblarz O. Rocket Propulsion Elements, Wiley, New York, USA, 7th Edition. 1992.

[19] Lide DA. CRC Handbook of Chemistry and Physics. 89th edition. Amazon.co. 2008.

[20] Thermo- Chemical Tables (National Institute of Standard Technology)NIST Chemistry. NO. 69 https://doi.org/10.18434/T4D303 2018, 2018

[21] Joint Army-Navy-NASA-Air Force (JANNAF), 2020

[22] Nakka R. Solid Propellant Burn Rate, Experimental Rocketry Web. 2013;5, Nov. 